\title{
Investigation of physical and chemical properties of new derivatives of 5-(thiophene-3-ylmethyl)-4R-1,2,4-triazole-3-thiols
}

\author{
A. V. Khilkovets (1D* \\ Zaporizhzhia State Medical University, Ukraine
}

Heterocyclic compounds are one of the most important branches of modern organic chemistry and are widely used in medicine, pharmacy, agriculture, and in the production of new materials. One of these compounds is 1,2,4-triazole, which has attracted the attention of scientists around the world for many years.

The aim of the work is to synthesize new derivatives of 5-(thiophene-3-ylmethyl)-4R-1,2,4-triazole-3-thiols and study their physicalchemical properties, conducting primary pharmacological screening.

Materials and methods. Organic synthesis classical methods were used in the study, as well as a complex of physical-chemical analysis methods ( ${ }^{1} \mathrm{H}$ NMR spectroscopy, elemental analysis, Elisa and chromato-mass spectral studies) were done. Prediction of pharmacological activity was carried out by using the PASS online computer program.

Results. Two initial compounds were obtained: 5-(thiophene-3-ylmethyl)-4phenyl-1,2,4-triazole-3-thiol and 5-(thiophene-3-ylmethyl)-4H1,2,4-triazole-3-thiol. During their further chemical transformation, a number of new corresponding alkyl derivatives were obtained. The structure of the synthesized compounds was confirmed using modern physical-chemical methods of analysis. Based on the results of pharmacological screening, the high activity of the obtained compounds can be predicted.

Conclusions. 5-(thiophene-3-ylmethyl)-4H-1,2,4-triazole-3-thiol, 5-(thiophene-3-ylmethyl)-4-phenyl-1,2,4-triazole-3-thiol and a number of their alkyl derivatives were synthesized. The structure and individuality were proved thanks to modern physical and chemical methods of analysis. Having analyzed the results of primary pharmacological screening of a number of obtained compounds, some of them were selected for further study.

Key words: 5-(thiophene-3-ylmethyl)-4-R-1,2,4-triazole-3-thiol, synthesis, physical and chemical properties.

Current issues in pharmacy and medicine: science and practice 2021; 14 (2), 152-156

Дослідження фізико-хімічних властивостей нових похідних 5-(тіофен-3-ілметил)-4R-1,2,4-тріазол-3-тіолів

А. В. Хільковець

Гетероциклічні сполуки - один із найважливіших розділів сучасної органічної хімії, що широко застосовуються в медицині, фрармації, сільському господарстві та під час отримання нових матеріалів. Одна з таких сполук - 1,2,4-тріазол, який протягом багатьох років привертає увагу науковців усього світу.

Мета роботи - синтез нових похідних 5-(тіофен-3-ілметил)-4R-1,2,4-тріазол-3-тіолів і дослідження їхніх фізико-хімічних властивостей, здійснення первинного фармакологічного скринінгу.

Матеріали та методи. Під час дослідження використали класичні методики органічного синтезу, а також застосували комплекс фізико-хімічних методів аналізу ('Н ЯМР спектроскопія, елементний аналіз, ІЧ та хромато-мас-спектральні дослідження). Прогнозування фармакологічної активності здійснили за допомогою комп'ютерної програми PASS online.

Результати. Отримали дві вихідні сполуки: 5-(тіофен-3-ілметил)-4феніл-1,2,4-тріазол-3-тіол і 5-(тіофен-3-ілметил)-4Н-1,2,4тріазол-3-тіол. Під час наступних хімічних перетворень одержали ряд нових відповідних алкілпохідних. Структура синтезованих сполук підтверджена з використанням сучасних фізико-хімічних методів аналізу. За результатами фармакологічного скринінгу можна прогнозувати високу активність нових сполук.

Висновки. Синтезували 5-(тіофен-3-ілметил)-4Н-1,2,4-тріазол-3-тіол, 5-(тіофен-3-ілметил)-4-френіл-1,2,4-тріазол-3-тіол і ряд їхніх алкілпохідних. Будову та індивідуальність сполук довели з застосуванням сучасних фрізико-хімічних методів аналізу. Проаналізувавши результати первинного фрармакологічного скринінгу, деякі з ряду сполук обрали для наступних досліджень.

Ключові слова: 5-(тіофен-3-ілметил)-4-R-1,2,4-тріазол-3-тіол, синтез, фрізико-хімічні властивості.

Актуальні питання фрармацевтичної і медичної науки та практики. 2021. Т. 14, № 2(36). С. 152-156

ARTICLE

INFO

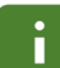

http:llpharmed.

zsmu.edu.ualarticle/

view/232334
UDC 615.31:547.79'3671.03/.04-047.37

DOI: $10.14739 / 2409-2932.2021 .2 .232334$

Current issues in pharmacy and medicine: science and practice 2021; 14 (2), 152-156

Key words: 5-(thiophene-3-ylmethyl)-4-R-1,2,4-triazole-3-thiol, synthesis, physical and chemical properties.

*E-mail: nastia010792@ukr.net

Received: 13.04.2021 // Revised: 26.04.2021 // Accepted: 05.05.2021 


\section{Исследование физико-химических свойств новых производных 5-(тиофен-3-илметил)-4R-1,2,4-триазол-3-тиолов}

\section{А. В. Хильковец}

Гетероциклические соединения - один из важнейших разделов современной органической химии, широко применяются в медицине, фармации, сельском хозяйстве и при получении новых материалов. Одно из таких соединений - 1,2,4-триазол, который в течение долгих лет привлекает внимание учёных всего мира.

Цель работы - синтез новых производных 5-(тиофен-3-илметил)-4R-1,2,4-триазол-3-тиолов и исследование их физико-химических свойств, проведение первичного фрармакологического скрининга.

Материалы и методы. В ходе исследования применяли методы классического органического синтеза, а также использован комплекс физико-химических методов анализа ('Н ЯМР спектроскопия, элементный анализ, ИК и хромато-масс-спектральные исследования). Прогнозирование фармакологической активности проведено с помощью компьютерной программы PASS online.

Результаты. Получены два исходных соединения: 5-(тиофен-3-илметил)-4фенил-1,2,4-триазол-3-тиол и 5-(тиофен-3-илметил)-4Н-1,2,4-триазол-3-тиол. В ходе дальнейших химических преобразований получен ряд новых соответствующих алкилпроизводных. Структура полученных соединений подтверждена современными фризико-химическими методами анализа. По результатам фармакологического скрининга можно спрогнозировать высокую активность полученных соединений.

Выводы. Синтезировали 5-(тиофен-3-илметил)-4Н-1,2,4-триазол-3-тиол, 5-(тиофен-3-илметил)-4-фенил-1,2,4-триазол-3-тиол и ряд их алкилпроизводных. Строение и индивидуальность доказаны с использованием современных физико-химических методов анализа. Проанализировав результаты первичного фармакологического скрининга, некоторые соединения из полученного ряда отобрали для дальнейших исследований.

Ключевые слова: 5-(тиофен-3-илметил)-4-R-1,2,4-триазол-3-тиол, синтез, физико-химические свойства.

Актуальные вопросы фармацевтической и медицинской науки и практики. 2021. Т. 14, № 2(36). С. 152-156

Heterocyclic compounds are one of the most important branches of modern organic chemistry and are widely used in medicine, pharmacy, agriculture, and in the production of new materials [1-3]. One of these compounds is 1,2,4-triazole, which has attracted the attention of scientists around the world for many years.

Despite a large amount of existing information on the study of 1,2,4-triazole derivatives, this topic still remains relevant, since these derivatives are potentially biologically active substances. Currently, there is a growing tendency in the scientific world to combine 1,2,4-triazole with various substituents, functional groups, as well as aromatic and heterocyclic fragments [4-6]. Such studies are undoubtedly promising and original. The new molecules obtained in this way exhibit a wide range of biological activity, and most of them are low-toxic, which is undoubted of great importance $[7,8]$. It is also interesting that the introduction of various pharmacophores into the molecule leads to the formation of new properties, which certainly opens opportunities for creating a new "ideal" compound.

According to the literature, we were convinced that the combination of 1,2,4-triazole and a five-membered heterocycle-thiophene is insufficiently studied. In our opinion, this combination is very promising, since the thiophene molecule is aromatic and has high reactivity. Existing data on the obtained thiophene-containing compounds have shown the presence of high biological activity and low toxicity.

\section{Aim}

The aim of the work is to synthesize new derivatives of 5-(thiophene-3-ylmethyl)-4R-1,2,4-triazole-3-thiols and study their physical-chemical properties, conducting primary pharmacological screening.

\section{Materials and methods of research}

Chemical names of compounds are given according to the IUPAC nomenclature (1979) and the IUPAC recommendations (1993). The study of the physical and chemical properties of the obtained substances was carried out by using the methods listed in the state Pharmacopoeia of Ukraine. The melting points were determined by the open capillary method on an OptiMelt MPA 100 instrument with a platinum RTD sensor. Element analysis was carried out by using the elementary vario EL cube analyzer (system Elementar Analysen, Germany). IR spectra (4000-400 $\mathrm{cm}^{-1}$ ) were obtained by using the ALPHA-t module of the Bruker ALPHA FT-IR spectrometer (Bruker optics, Germany). ${ }^{1} \mathrm{H}$ NMR spectra (400 MHz) were recorded on a Varian-MR 400 spectrometer with an internal SiMe4 standard in a DMSO-d6 solution. Chromato-mass-spectral studies were carried out on the Agilent 1260 Infinity HPLC device, which is equipped with an Agilent 6120 mass spectrometer (electrospray ionization method (ESI). The prediction of pharmacological activity was performed using the online computer program PASS.

To obtain new compounds, we used the generally accepted synthesis method [9], according to which 3-thiophenacetate acid was used as the starting substance. During further chemical transformations, the corresponding N-R-2-(2-(thiophene-3-yl)acetyl)hydrazine carbothioamides were obtained. The cycle was closed in an alkaline medium, and acetate acid was added to the neutral medium to further isolate the initial thiols. Thus, two starting substances were obtained: 5-(thiophene-3-ylmethyl)-4phenyl-1,2,4-triazole-3-thiol (1) and 5-(thiophene-3-ylmethyl)-4H-1,2,4-triazole-3-thiol (2) (Fig. 1).

The next step was to obtain a number of alkyl derivatives [3-9]. The reaction was carried out in an alcoholic medium by 


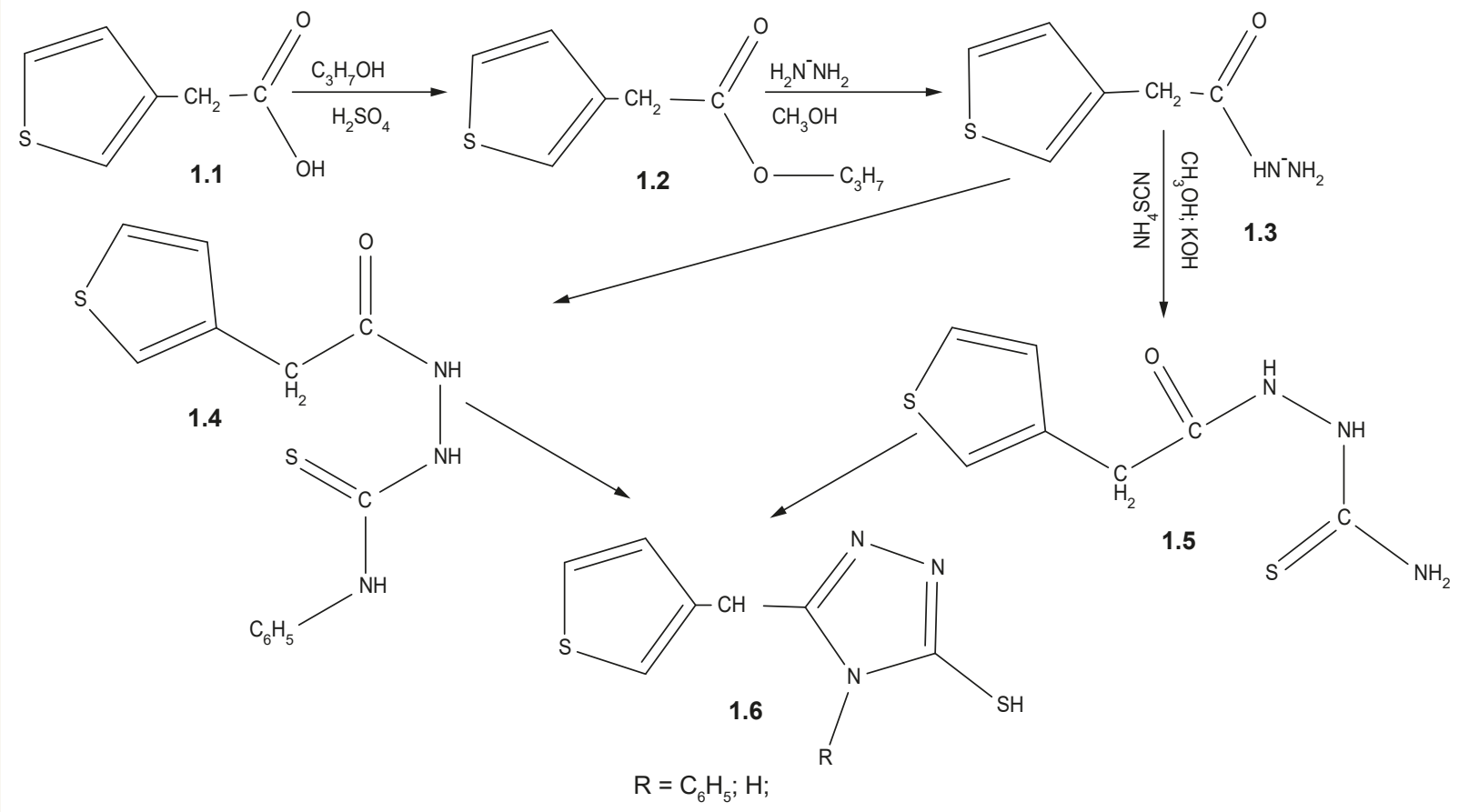

Fig. 1. The synthesis of 5-(thiophene-3-ylmethyl)-4phenyl-1,2,4-triazole-3-thiol (1) and 5-(thiophene-3-ylmethyl)-4H-1,2,4-triazole-3-thiol (2).

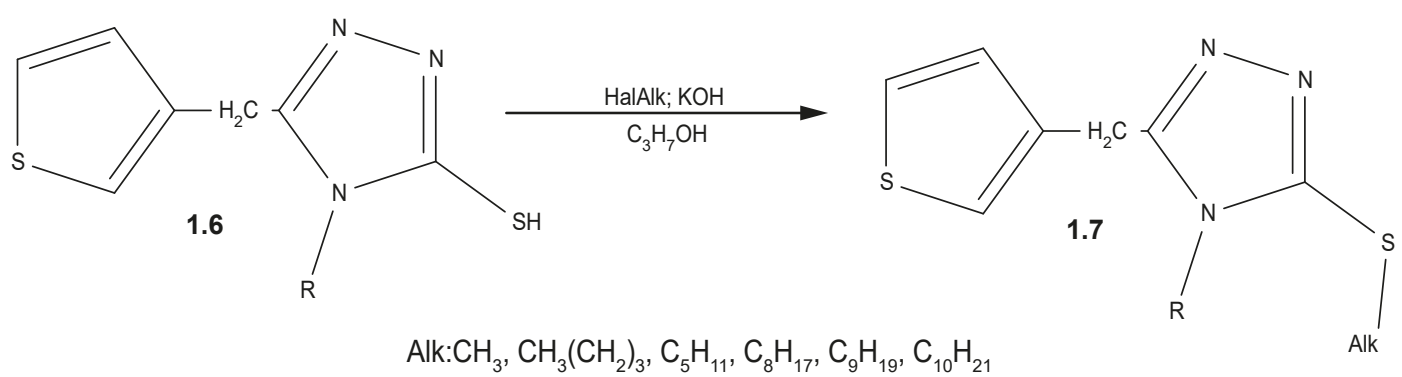

Fig. 2. The synthesis of haloalkanes.

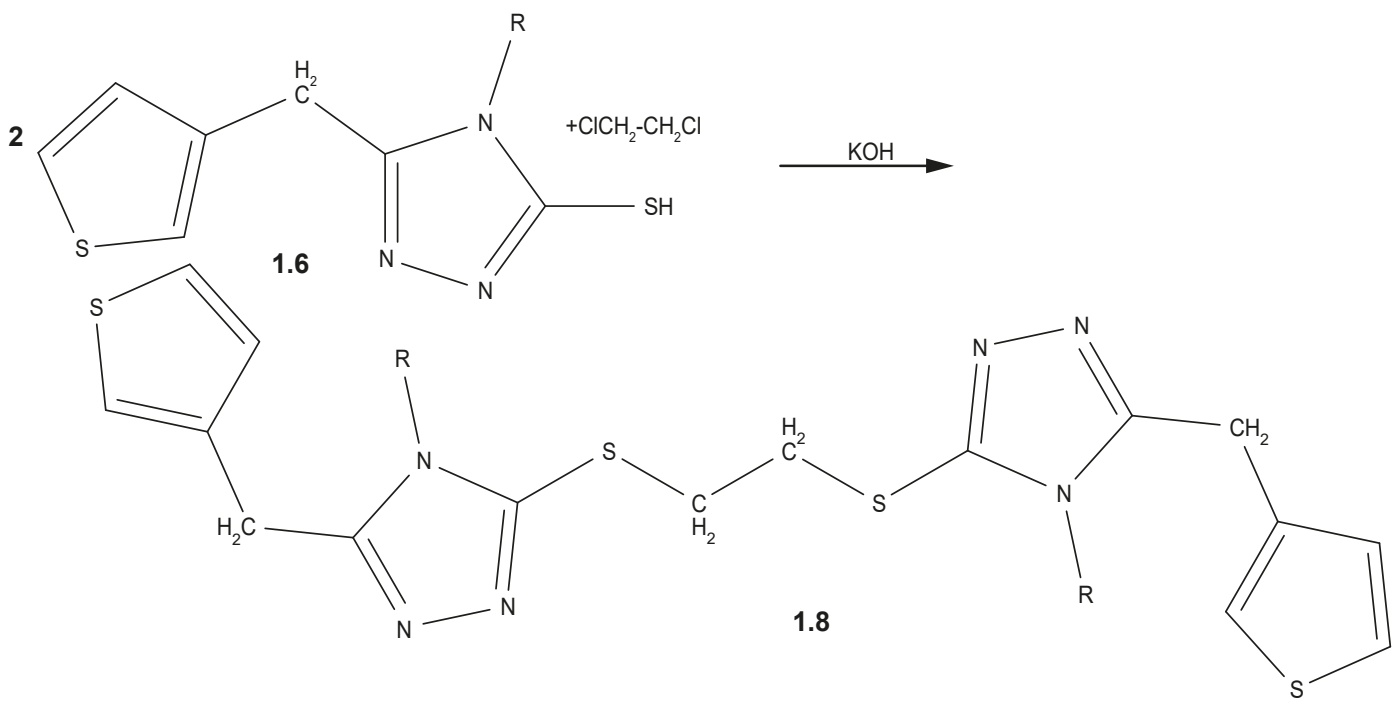

Fig. 3. The synthesis of dihaloalkanes. 
adding an equivalent amount of alkali to the initial thiols and corresponding haloalkanes (Fig. 2). In the case of dihaloalkanes, double the amount of Alkali was added (Fig. 3). The synthesized compounds were recrystallized from a mixture of methanol and water in various ratios.

\section{Results}

The IR spectra of the obtained compounds were characterized by the presence of clear bands of valence and other vibrations of strong and medium intensity of the main fragments of molecules. In the initial compounds, we observed valence vibrations $\mathrm{C}=\mathrm{C}$ in the region of $1620-1680 \mathrm{~cm}^{-1}, \mathrm{C}=\mathrm{N}$ in the cycle $-1480-1500 \mathrm{~cm}^{-1}$, as well as a high intensity of thiophene valence vibrations in the region of $690-750 \mathrm{~cm}^{-1}$. There were valence vibrations in the range of $255-2590 \mathrm{~cm}^{-1}$, which indicated the presence of the S-H group. Valence vibrations of the $\mathrm{CH}_{2}$ group were in the range of $2870-2940 \mathrm{~cm}^{-1}$, $\mathrm{CH}_{3}-2950-2975 \mathrm{~cm}^{-1}$, and deformation vibrations of the $\mathrm{S}-\mathrm{CH}_{3}$ group in the region of $1325 \mathrm{~cm}^{-1}$ are clearly observed in the alkyl derivatives which we obtained.

4-phenyl-5-(thiophen-3-ylmethyl)-1,2,4-triazole-3-thiol(1) Yield.: 75 \%; Mp.: $188-190{ }^{\circ} \mathrm{C}$; ${ }^{1} \mathrm{H}$ NMR (400 MHz, DMSO-d $) \delta: ~ 7.46-7.52\left(\mathrm{~m}, 3 \mathrm{H}-14,15,16 \mathrm{C}_{6} \mathrm{H}_{5}\right), 7.22-7.29(\mathrm{~m}$, $\left.2 \mathrm{H}-13,17 \mathrm{C}_{6} \mathrm{H}_{5}\right), 6,96(\mathrm{~s}, 1 \mathrm{H}-2$ tiophen), $6.75(\mathrm{~d}, \mathrm{~J}=4.58 \mathrm{~Hz}$, 2H-3,4 tiophen), 3.85 (s, 2H, $\mathrm{CH}_{2}$ ); Anal. Calcd. (\%): C 57.12, H 4.06, N 15.37, S 23.46. Found: C 57.29, H 4.05, N 15.33.

5-(thiophen-3-ylmethyl)-4H-1,2,4-triazole-3-thiol (2) Yield.: $56 \%$; Mp.: $178-180{ }^{\circ} \mathrm{C}$; ${ }^{1} \mathrm{H}$ NMR (400 MHz, DMSO-d $)_{6} \delta: 7.49$ (dd, J = 4.73, $2.90 \mathrm{~Hz}, 1 \mathrm{H}-2$ tiophen); 7.30 (s, 1H-5 tiophen), 7.03 (d, J = 4.88 Hz, 1H-4 tiophen), 3.89 (s, 2H, $\mathrm{CH}_{2}$ ); Anal. Calcd. (\%): C 42.62, H 3.58, N 21.30, S 32.50. Found: C 42.58, H 3.58, N 21.29, S 32.57.

3-(pentylthio)-4-phenyl-5-(thiophen-3-ylmethyl)-1,2,4-triazole (3) Yield.: $75 \%$; Mp.: $169-171^{\circ} \mathrm{C}$; ${ }^{1} \mathrm{H} \mathrm{NMR}(400 \mathrm{MHz}$, DMSO-d $) \delta: ~ 7.46-7.56\left(m, 3 \mathrm{H}-14,15,16 \mathrm{C}_{6} \mathrm{H}_{5}\right), 7.30-7.42$ (m, 2H-13,17 $\left.\mathrm{C}_{6} \mathrm{H}_{5}\right), 7.25$ (d, J = 4.58 Hz, 1H-4 tiophen), 6.89 (s, 1H-5 tiophen), 6.71 (d, J = 4.58 Hz, 1H-2 tiophen), $3.93\left(\mathrm{~s}, 2 \mathrm{H}, \mathrm{CH}_{2}\right), 3.29$ (s, 2H, $\left.\mathrm{CH}_{2}\right), 2.97-3.06$ (m, 2H, $\left.\mathrm{CH}_{2}\right), 1.52-1.63\left(\mathrm{~m}, 2 \mathrm{H}, \mathrm{CH}_{2}\right), 1.23\left(\mathrm{~s}, 2 \mathrm{H}, \mathrm{CH}_{2}\right), 0.80(\mathrm{~d}$, $\left.\mathrm{J}=6.71 \mathrm{~Hz}, 3 \mathrm{H}, \mathrm{CH}_{3}\right) ; \mathrm{m} / \mathrm{z}=343.10[\mathrm{M}+1]$; Anal. Calcd. (\%): C 62.94, H 6.16, N 12.23, S 18.67. Found: C 62.95, H 6.17, N 12.22, S 18.65 .

3-(butylthio)-5-(thiophen-3-ylmethyl)-4H-1,2,4-triazole (4) Yield.: $73 \%$; Mp.: 137-139 ${ }^{\circ} \mathrm{C}$; ${ }^{1} \mathrm{H}$ NMR (400 MHz, DMSO-d $\left.{ }_{6}\right) \delta:$ 6.92-7.52 (m, 3H-2,4,5 tiophen), 3.98 (s, 2H, $\left.\mathrm{CH}_{2}\right), 2.94-3.08\left(\mathrm{~m}, 2 \mathrm{H}, \mathrm{CH}_{2}\right), 1.51-1.62\left(\mathrm{~m}, 2 \mathrm{H}, \mathrm{CH}_{2}\right), 1.34$ $\left(\mathrm{m}, \mathrm{J}=7.32 \mathrm{~Hz}, 2 \mathrm{H}, \mathrm{CH}_{2}\right), 0.79-0.90\left(\mathrm{~m}, 3 \mathrm{H}, \mathrm{CH}_{3}\right) ; \mathrm{m} / \mathrm{z}=$ 253.10 [M+1]; Anal. Calcd. (\%): C 52.14, H 5.97, N 16.58, S 25.31. Found: C 52.28, H 5.98, N 16.54, S 25.28.

3-(methylthio)-4-phenyl-5-(thiophen-3-ylmethyl)-1,2,4-triazole (5) Yield.: $76 \%$; Mp.: $175-177^{\circ} \mathrm{C}$; ${ }^{1} \mathrm{H} \mathrm{NMR}(400 \mathrm{MHz}$, DMSO-d6) $\delta:$ 7.44-7.53 (m, 3H-14,15,16 $\left.\mathrm{C}_{6} \mathrm{H}_{5}\right), 7.30-7.41$ (m, 2H-13,17 $\left.\mathrm{C}_{6} \mathrm{H}_{5}\right), 7.20-7.30$ (m, 2H-2,5 tiophen), 6.71 (d, $\mathrm{J}=4.58 \mathrm{~Hz}, 1 \mathrm{H}-4$ tiophen), $3.94\left(\mathrm{~s}, 2 \mathrm{H}, \mathrm{CH}_{2}\right), 2.51(\mathrm{~s}, 3 \mathrm{H}$, $\mathrm{CH}_{3}$ ); $\mathrm{m} / \mathrm{z}=287.0$ [M+1]; Anal. Calcd. (\%): C 58.51, H 4.56, N 14.62, S 22.31. Found: C 58.43, H 4.55, N 14.58, S 22.35.
3-(methylthio)-5-(thiophen-3-ylmethyl)-4H-1,2,4-triazole (6) Yield.: $68 \%$; Mp.: 124-126 ${ }^{\circ} \mathrm{C}$; ${ }^{1} \mathrm{H}$ NMR (400 MHz, DMSO-d $) \delta: 7.22-7.53$ (m, 1H-2 tiophen), 7.00-7.06 (m, $2 \mathrm{H}-4,5$ tiophen), $4.04\left(\mathrm{~s}, 2 \mathrm{H}, \mathrm{CH}_{2}\right), 3.32\left(\mathrm{~s}, 3 \mathrm{H}, \mathrm{CH}_{3}\right) ; \mathrm{m} / \mathrm{z}=$ 211.0 [M+1]; Anal. Calcd. (\%): C 45.47, H 4.29, N 19.89, S 30.35. Found: C 45.53, H 4.30, N 19.89, S 30.42.

3-(butylthio)-4-phenyl-5-(thiophen-3-ylmethyl)-1,2,4-triazole (7) Yield.: $65 \%$; Mp.: $87-89{ }^{\circ} \mathrm{C} ; \mathrm{m} / \mathrm{z}=329.10[\mathrm{M}+1]$.

3-(octylthio)-5-(thiophen-3-ylmethyl)-4H-1,2,4-triazole (8) Yield.: $71 \%$; Mp.: $67-69^{\circ} \mathrm{C} ; \mathrm{m} / \mathrm{z}=309.10$ [M+1]; Anal. Calcd. (\%): C 58, H 7.49, N 13.58, S 20.72. Found: C 58.05, H 7.50, N 13.59, S 20.77.

3-(decylthio)-5-(thiophen-3-ylmethyl)-4H-1,2,4-triazole (9) Yield.: 69\%; Mp.: 85-87 ${ }^{\circ} \mathrm{C}$; ${ }^{1} \mathrm{H}$ NMR (400 MHz, DMSO-d $)$ $\delta: 7.42$ (s, 1H-5 tiophen), 7.21 (s, 1H-4 tiophen), 6.98 (d, J $=4.88 \mathrm{~Hz}, 1 \mathrm{H}-2$ tiophen $), 3.99\left(\mathrm{~s}, 2 \mathrm{H}, \mathrm{CH}_{2}\right), 3.29(\mathrm{~s}, 2 \mathrm{H}$, $\mathrm{CH}_{2}$ ), 1.53-1.62 (m, 6H, $\left.\mathrm{CH}_{2}\right), 1.16-1.36\left(\mathrm{~m}, 10 \mathrm{H}, \mathrm{CH}_{2}\right)$, 0.76-0.85 (m, 3H, $\left.\mathrm{CH}_{3}\right) ; \mathrm{m} / \mathrm{z}=337.20$ [M+1]; Anal. Calcd. (\%): C 60.49, H 8.06, N 12.45, S 19.00. Found: C 60.53, H 8.05, N 12.46, S 19.04 .

3-(decylthio)-4-phenyl-5-(thiophen-3-ylmethyl)-1,2,4-triazole (10) Yield.: $64 \%$; Mp.: 82-84 ${ }^{\circ} \mathrm{C} ; \mathrm{m} / \mathrm{z}=413.20[\mathrm{M}+1]$.

3-(nonylthio)-4-phenyl-5-(thiophen-3-ylmethyl)-1,2,4-triazole (11) Yield.: $62 \%$; Mp.: $78-90{ }^{\circ} \mathrm{C} ; \mathrm{m} / \mathrm{z}=399.20$ [M+1].

2-((4-phenyl-5-(thiophen-3-ylmethyl)-1,2,4-triazol-3-yl) thio)ethan-1-ol (12) Yield.: 67\%; Mp.: 82-84 ${ }^{\circ} \mathrm{C}$; Anal. Calcd. (\%): C 56.76, H 4.76, N 13.24, S 20.10. Found: C 56.60, H 4.75, N 13.20, S 20.19.

2-((5-(thiophen-3-ylmethyl)-4H-1,2,4-triazol-3-yl)thio) ethan-1-ol (13) Yield.: $65 \%$; Mp.: $185-187^{\circ} \mathrm{C}$; Anal. Calcd. (\%): C 42.27, H 3.99, N 18.49, S 28.21. Found: C 42.24, H $3.98, \mathrm{~N} 18.45$, S 28.18 .

Due to the prediction of pharmacological activity using the PASS online computer program, a fairly wide range of possible activities was identified. For the initial compound 4-phenyl-5-(thiophen-3-ylmethyl)-1,2,4-triazole-3-thiol (1) and its alkyl derivatives $(3,5,7,10,11,12)$ the following types of activity were predicted: anti-atherosclerotic $-52 \%$, analgesic $-48 \%$, antioxidant $-45 \%$, calcium channel blockers $-47 \%$ and as a means for the treatment of stroke $48 \%$. It is predicted with high probability that the compound 5-(thiophen-3-ylmethyl)-4H-1,2,4-triazole-3-thiol (2) and its alkyl derivatives $(4,6,8,9,13)$ show: anti-inflammatory activity $-90 \%$, antiplatelet $-47 \%$, dermatological $-42 \%$, inhibition of angiogenesis $-80 \%$ and also as a means for the symptomatic treatment of diabetes mellitus $-42 \%$.

\section{Discussion}

The structure and individuality of the obtained compounds were proved thanks to modern physical-chemical methods of analysis.

Careful analysis of the ${ }^{1} \mathrm{H}$ NMR spectra indicates the production of new alkyl derivatives. On the spectrums, in the region typical for aromatic compounds, there were characteristic signals of the phenyl radical in the form of multiplets. Thiophene cycle signals in the form of singlet and doublet 
were also observed in the same region. A clear methylene linker signal between the thiophene and 1,2,4-triazole heterocycle was present as a singlet. Successful alkylation was indicated by the presence of a series of duplets, singlets, and multiplets, which indicated the addition of an alkyl radical along the sulphor atom, for example in compound 3-(pentylthio)-4-phenyl-5-(thiophen-3-ylmethyl)-1,2,4-triazole (3): 3.29 (s, 2H, CH $\left.\mathrm{CH}_{2}\right), 2.97-3.06\left(\mathrm{~m}, 2 \mathrm{H}, \mathrm{CH}_{2}\right), 1.52-1.63(\mathrm{~m}$, $\left.2 \mathrm{H}, \mathrm{CH}_{2}\right), 1.23\left(\mathrm{~s}, 2 \mathrm{H}, \mathrm{CH}_{2}\right), 0.80\left(\mathrm{~d}, \mathrm{~J}=6.71 \mathrm{~Hz}, 3 \mathrm{H}, \mathrm{CH}_{3}\right)$.

\section{Conclusions}

1. A number of new S-alkyl derivatives of 5-(thiophene-3ylmethyl)-4phenyl-1,2,4-triazole-3-thiols and 5-(thiophene3-ylmethyl)-4H-1,2,4-triazole-3-thiols were synthesized.

2 . The individuality and the structure of the obtained compounds were proved by using a complex of modern physical-chemical methods of analysis.

Prospects for further researches. Having analyzed the results of primary pharmacological screening, some promising compounds were selected for further, more in-depth study.

Conflicts of interest: author has no conflict of interest to declare Конфлікт інтересів: відсутній.

Information about author:

Khilkovets A. V., PhD-student of the Department of Natural Sciences for Foreign Students and Toxicological Chemistry, Zaporizhzhia State Medical University, Ukraine.

ORCID ID: 0000-0001-7401-9458

\section{Відомості про автора:}

Хільковець А. В., аспірант каф. природничих дисциплін для іноземних студентів та токсикологічної хімії, Запорізький державний медичний університет, Україна.

\section{Сведения об авторе:}

Хильковец А. В., аспирант каф. естественных дисциплин для иностранных студентов и токсикологической химии, Запорожский государственный медицинский университет, Украина.

\section{References}

[1] Borisenko, N. N., Bushueva, I. V., Parchenko, V. V., Gubenko, I. Ya., Mykhailiuk, Ye. O., Riznyk, O. I., Aleksieiev, O. G., Gutyj, B. V., Lysianska, H. P., \& Kurinnyi, A. V. (2019). Anti-Inflammatory, Antiviral Veterinary Medicine with Immuno-Modulating Activity. Research Journal of Pharmacy and Technology, 12(11), 5255-5259. https://doi. org/10.5958/0974-360X.2019.00909.0

[2] Vashchyk Y., Shcherbyna R., Parchenko V., Bushueva I., Gutyj B., Fotina H. (2020). Histological study of a corrective influence of a compound potassium 2-((4-amino-5-(morpholinomethyl)-4H-1,2,4triazol-3-yl)thio)acetate (PKR-173) on the state of chicken's liver under infection by pseudomonas aeruginosa. Ankara Universitesi Eczacilik Fakultesi Dergisi, 44(1), 1-17. https://doi.org/10.33483/ifpau.567757

[3] Bihdan, O., Gotsulya, A., Parchenko, V., \& Izhboldin, O. (2019). Influence of different determination of 1,2,4-triazols on the growth, development and yield of grain sorghum. Research Journal of Pharmaceutical, Biological and Chemical Sciences, 10(2), 1156-1160.

[4] Hotsulia, A. S., \& Fedotov S. O. (2020). Synthesis and properties of 5-(((5-amino-1,3,4-thiadiazole-2-yl)thio)methyl)-4-phenyl-1,2,4triazole-3-thione and its some S-derivatives. Current issues in pharmacy and medicine: science and practice, 13(2), 182-186. https://doi. org/10.14739/2409-2932.2020.2.207062

[5] Bushuieva, I. V., Klyosova, K. G., Parchenko, V. V., Gudzenko, O. P., Gutyj, B. V., Polova, Z. M., Olkhovska, A. B., Mykhailiuk, Y. O.,
Kurinnyi, A. V., Gladysheva, S. A., \& Odyntsova, V. M. (2020). Influence of the carrier type and surfactants on the trifuzole emission from veterinary intrauterine suppositories. Research Journal of Pharmacy and Technology, 13(11), 5407-5410. https://doi.org/10.5958/0974360X.2020.00945.2

[6] Bihdan, O., Parchenko, V., \& Zazharskyi, V. (2019). Studying of physico-chemical properties of 5-(2-,3-fluorophenyl)-4-((aryl-, geteryl) yliden) amino-1,2,4-triazole-3-thiols and any of their retrievalproducts. Research Journal of Pharmaceutical, Biological and Chemical Sciences, 10(1), 464-474.

[7] Zazharskyi, V., Parchenko, M., Parchenko, V., Davydenko, P., Kulishenko, O., \& Zazharska, N. (2020). Physicochemical properties of new S-derivatives of 5-(5-bromofuran-2-yl)-4-methyl-1,2,4-triazol3-thiols. Voprosy Khimii i Khimicheskoi Tekhnologii, 6, 50-58. https:// doi.org/10.32434/0321-4095-2020-133-6-50-58

[8] Hunchak, V. M., Martynyshyn, V. P., Gutyj, B. V., Hunchak, A. V., Stefanyshyn, O. M., \& Parchenko, V. V. (2020). Impact of 1,2,4-thio-triazole derivative-based liniment on morphological and immunological blood parameters of dogs suffering from dermatomycoses. Regulatory Mechanisms in Biosystems, 11(2), 294-298. https://doi. org/10.15421/022044

[9] Parchenko, V. V. (2014). Syntez, peretvorennia, fizyko-khimichni ta biolohichni vlastyvosti v riadi 5-furylzamishchenykh 1,2,4-triazol-3-tioniv (Dis. dokt. farm. nauk) [Synthesis, transformation, physico-chemical and biological properties in the number of 5-furylsubstituted 1,2,4-triazole-3-thiones (Doctoral dissertation)]. Zaporizhzhia State Medical University, Zaporizhzhia. [in Ukrainian]. 